Cahiers $d u$ MONDE RUSSE

\section{Cahiers du monde russe}

Russie - Empire russe - Union soviétique et États indépendants

$57 / 4 \mid 2016$

Varia

\title{
Evropeiskii Printsip Vybornosti V Rossii Pervoi Chetverti XIX Veka
}

Ideal'nye modeli i praktiki realizatsii

Le principe électif européen dans la Russie du premier quart du XIX siècle :

modèles idéaux et mises en pratique

The European elective principle and electoral practice in Russia in the first quarter of the nineteenth century

\section{Dmitrii V. Timofeev}

\section{(2) OpenEdition}

Journals

\section{Édition électronique}

URL : http://journals.openedition.org/monderusse/9987

DOI : 10.4000/monderusse. 9987

ISSN : $1777-5388$

\section{Éditeur}

Éditions de l'EHESS

\section{Édition imprimée}

Date de publication : 1 octobre 2016

Pagination : 743-764

ISBN : 978-2-7132-2542-0

ISSN : $1252-6576$

\section{Référence électronique}

Dmitrii V. Timofeev, «Evropeiskii Printsip Vybornosti V Rossii Pervoi Chetverti XIX Veka », Cahiers du monde russe [Онлайн], 57/4 | 2016, Выложить онлайн 01 octobre 2018, Наводить справки в 05 janvier 2020. URL : http://journals.openedition.org/monderusse/9987 ; DOI : 10.4000/monderusse. 9987 


\title{
EVROPEISKII PRINTSIP VYBORNOSTI V ROSSII PERVOI CHETVERTI XIX VEKA
}

\author{
Ideal'nye modeli i praktiki realizatsii \\ [The European elective principle and electoral practice \\ in Russia in the first quarter \\ of the nineteenth century $]^{1}$
}

Заимствование социально-политических теорий и концепций, их адаптация к новым социокультурным, политическим и экономическим условиям распространения является одним из ключевых процессов, оказывающих заметное влияние не только на характер взаимоотношений между различными странами, но и на процесс внутреннего саморазвития общества. Именно поэтому изучение культурных механизмов адаптации инноваций является важной и актуальной темой для исторического исследования. Сложность ретроспективной реконструкции данного процесса обусловлена его многофакторностью, отсутствием общего шаблона для восприятия инноваций в различных социальных и языковых средах.

Проникая в новую культурную среду, заимствованные извне идеалы и принципы, распространяются неравномерно в различных социальных группах. Наиболее образованная часть общества, особенно, если ее представители владеют иностранным языком и имеют возможность сравнивать положение в своей стране с особенностями политической и социально-экономической обстановки в других странах, может вполне адекватно понять теоретические основы заимствованных политических и экономических концепций.

1. Статья подготовлена в рамках реализации гранта Правительства РФ по привлечению ведущих учёных в российские образовательные учреждения высшего профессионального образования и научные учреждения государственных академий наук и государственные научные центры Российской Федерации, договор № 14.A12.31.0004 от 26.06.2013 г. 
Однако даже в этой образованной среде не исключается возможность упрощения идеалов, наполнение их новым, утилитарно ориентированным содержанием. Одновременно, различные элементы инноваций могут проникать и в более широкие социальные слои, но, лишь фрагментарно, утрачивая при этом сложную теоретическую основу. Все это обусловливает своеобразную «девиацию» содержания заимствований посредством смещения смысловых акцентов и последующей интеграции инноваций в контекст имеющегося социального опыта.

В рамках конкретно-исторического исследования реконструкция процесса адаптации должна сопровождаться обращением к различным формам социальной практики: от написания текстов, предназначенных для публикации на страницах периодической печати; составления всеподданнейших прошений и проектов, - до утилитарно ориентированных действий индивида, необходимость совершения которых обосновывалась посредством апелляции к заимствованным принципам. Весь этот спектр проявления социальной активности индивида сопровождался созданием разнообразных по своему функциональному назначению текстов, сопоставление которых открывает перед исследователем перспективу понимания процесса девиации заимствований на двух одновременно существовавших, уровнях. Первый их них - проектный, отражавший представление о перспективах общественного развития, второй - утилитарно-прагматический, который в большей степени был связан с практическим применением заимствованных идей для достижения вполне конкретных целей в определенный временной период. Конечно, предложенное разделение на «проектный» и «утилитарно-прагматический» уровень во многом условно, т.к. они не только одновременно сосуществовали в сознании отдельного индивида, но и взаимодополняли друг друга, создавая ситуацию выбора между идеальной моделью и сложившимися в обществе стереотипами и поведенческими моделями.

В современной историографии аналогичная проблематика представлена в работах А.И. Куприянова ${ }^{2}$. Автор рассматривает выборные процедуры в дворянских собраниях в контексте поиска ответа на вопрос: были ли они элементом формирующегося гражданского общества, или привилегированными сообществами, использовавшими механизмы квазидемократического самоуправления? При всей важности такой постановки вопроса не менее интересной и актуальной представляется проблема соотношения теоретических концептуальных моделей использования принципа выборности в проектах различного уровня и в повседневной практике избрания на выборные должности.

2. См. подробнее: А.И. Куприянов, «Городская демократия: выборы в русской провинции (вторая половина 1780 х - начало 1860х гг.)», Отечественная история, 2007, № 5, с. 31-49; А.И. Куприянов, «Дворянские выборы в последней четверти XVIII-первой трети XIX века: от сословной корпорации к институту гражданского общества?», Российская история, 2012, № 1, с. 30-43; А.И. Куприянов, «Электоральное поведение русского дворянина (1770-1820-е гг.)», Вестник РУДН, Сер.: история России, 2012, № 1, с. 5-19. 
С учетом обозначенных выше теоретико-методологических размышлений в данной статье рассматривается проблема встраивания выборных процедур в социально-политический ландшафт России конца XVIII - первой четверти XIX века. При этом основной акцент делается не на правовых аспектах данного процесса ${ }^{3}$, а на субъективных оценках современниками эффективности выборных процедур как способа подбора кадров для органов местного управления и судопроизводства, а также электоральном поведении участвующих в выборах дворян ${ }^{4}$. В данном контексте, в качестве проявления субъективных оценочных суждений, использовались, с одной стороны, различные проекты и записки, авторы которых предлагали расширить границы сферы применения принципа выборности для повышения эффективности системы управления, а с другой, - жалобы и прошения по вопросам организации и проведения выборов.

\section{Проектирование выборности: факторы и границы применения}

Элементы выборности не были для России абсолютно новым феноменом, однако именно во второй половине XVIII в., на фоне распространения идей европейского просвещения и действий Екатерины II по модернизации российского законодательства, они приобрели новые формально-юридические формы и порождали соответствующие поведенческие практики ${ }^{5}$. Пожалованное императрицей Екатериной II право выбирать кандидатов на целый ряд должностей в местной администрации и судах было законодательно закреплено 7 ноября 1775 г. в «Учреждении для управления губерний Всероссийской империи», а также 21 апреля 1785 г. в «Грамоте на права и выгоды городам Российской империи» и «Грамоте на права, вольности и преимущества благородного российского дворянства». В соответствии с пунктами 62-65 «Жалованной грамоты дворянству», право голоса получили: дворяне, владеющие недвижимым имением доходностью не менее 100 руб. в год; достигшие

3. История юридического оформления выборных институтов достаточно полно представлена в исследованиях как дореволюционных, так и современных авторов. См., например: В.В. Водовозов, Избирательное право в Европе и России, СПб., 1906; А.А. Кизеветтер, Городовое положение Екатерины II 1785 года: опыт исторического комментария, М., 1909; А.К. Семенов, «Городская гражданская реформа Екатерины II и выборы в городах Центрального Черноземья», Вопросы истории, 2006, № 5, с. 97-103; И.В. Минникес, Выборы в истории Российского государства в IX-начале ХІХ века, СПб.: Юридический центр Пресс, 2010.

4. В данной статье предметное поле исследования сознательно ограничено только представлениями дворян и не затрагивает целый ряд категорий городских жителей, которые также имели право участвовать в выборах в соответствии с «Грамотой на права и выгоды городам Российской империи».

5. См. подробнее об истории выборных институтов в России до времени правления Екатерины II: Институт выборов в истории России: источники, свидетельства современников. Взгляды исследователей ХIX - начала ХХ вв. М.: Норма, 2001; С.В. Красильников, «Формирование органов местного самоуправления и системы выборов в Российской империи XVIII века», История государства и права, 2008, № 8, с. 13-15. 
возраста 25 лет, и дослужившиеся «...хотя бы до обер-офицерского чина» ${ }^{6}$. К выборам мог быть не допущен дворянин, в случае, если он «...опорочен судом, или которого явный и бесчестный порок всем известен, хотя бы и судим еще не был, пока оправдается» ${ }^{7}$. Практически в неизменном виде, за исключением нескольких лет правления императора Павла I, когда действие Жалованной грамоты дворянству было существенно сокращено, такой порядок избрания на выборные должности сохранился к началу XIX в.

К этому времени наличие у дворянства права участвовать в выборах воспринималось как важнейший элемент системы привилегий «благородного» сословия. Понимая это, Александр I стремился заручиться поддержкой дворянства и уже через несколько дней после восшествия на престол издал 15 марта 1801 г. указ «О восстановлении дворянских выборов», а 2 апреля - манифесты «О восстановлении жалованной дворянству грамоты» и «О восстановлении Городового положения и грамоты данной городам» ${ }^{8}$. Таким образом в начале XIX в. выборы, как процедура формирования органов дворянского самоуправления и местных администраций, была признана верховной властью одним из действенных способов повышения эффективности системы местного управления.

Дополнительным фактором, оказывавшим влияние на отношение дворянства к принципу выборности, было знакомство образованной части российского общества с основными положениями конституций различных стран мира, тексты которых печатались в журналах «Сын Отечества», «Русский Вестник», «Отечественные записки», «Дух журналов», «Вестник Европы». На страницах этих журналов были опубликованы переведенные на русский язык выдержки из текстов конституции Итальянской республики; Вестфальского королевства; конституции С.-Маринской республики; Испанского королевства; Конституции Французского королевства; Нидерландского Королевства; конституции Норвежского государства, конституции Царства Польского; Великого герцогства Баденского; Баварского королевства, Северо-Американских Соединенных областей ${ }^{9}$. Основные положения английской системы

6. ПСЗ (Полное собрание законов Российской империи), СПб., 1830, т. XXII, 1785, № 16.186 , c. 351 .

7. ПСЗ, т. XXII, 1785, № 16.186, с. 351.

8. ПСЗ, т. XXVI, 1801. №19.790, с. 590; т. XXVI, 1801, №19.811, с. 602.

9. «Конституция Италиянской республики», Вестник Eвропьл, 1802, ч. II, № 5, март, с. 71-79; «Существенное содержание конституции Вестфальского королевства», Политический, статистический и географический журнал, или современная история света на 1807 год, 1807, ч. 4, кн. 2, ноябрь, с. 155-157; «С.-Маринская республика. Письмо одного немецкого путешественника в 1801 году», Вестник Европы, 1802, ч, VI., № 21, ноябрь, с. 63-69; «Государственный устав Испанской Монархии», Вестник Европьl, 1813, ч. LXX, № 13, с. 48-67; № 14, с. 130-132; «Конституция Французского королевства», Сын Отечества, 1814, ч.13, №XVII, с. 193-197; ч. 14, № XXV, с. 259-270; «О новом Государственном Уставе Нидерландского Королевства», Вестник Европы, 1815, ч. 83, №17, с. 55-58; «О конституции Норвежского государства», Вестник Eвропь, 1816, ч. 88, № 16, с. 284-295; «О конституции Польского Царства», Вестник Eвponbl, 1816, ч. ХС, № 22, с. 137-145; ч. 83, № 17, с. 55-58; «Государственное уложение Великого герцогства 
управления, которую современники, несмотря на отсутствие конституции как единого документа, обозначали словосочетанием «Английская конституция», также освещалась на страницах российской периодической печати ${ }^{10}$. Практически во всех публикациях такого рода читателям предлагалось познакомиться с системой государственного управления и порядком формирования выборных органов сословного представительства. При этом, как правило, текст конституций предварял комментарий от имени издателя журнала, в котором принцип выборности преподносился как отражение одной из заметных тенденций в эволюции системы управления различных стран мира.

На этом фоне восстановление в полном объеме положений «жалованных грамот» дворянству и городам, а также заявления императора о необходимости укрепления «силы закона» и утверждение конституции Царства Польского, создавало иллюзию, что Российская империя движется в том же направлении, что и наиболее развитые страны Европы. На уровне высокопоставленных чиновников, приближенных к особе Его императорского Величества, такая иллюзия могла подкрепляться личными пожеланиями монарха разработать проект конституции для Российской империи, в которой, наряду с законодательным закреплением «естественных» прав и свобод, определенная категория граждан могла быть наделена «политическими правами», то есть правом избирать и быть избранными. Именно такой вариант реализации принципа выборности был предложен в хорошо известных исследователям конституционных проектах М.М. Сперанского, Н.Н. Новосильцова, А.Р. Воронцова ${ }^{11}$, а также в ряде записок Н.С. Мордвинова и Г.Р. Державина ${ }^{12}$.

Таким образом, осмысление европейского принципа выборности происходило, одновременно, под влиянием образцов европейского парламентаризма и российского опыта функционирования выборных органов дворянского и городского самоуправления. Последнее обстоятельство актуализирует вопрос о влиянии личного опыта участия в работе дворянских собраний на содержание проектов реформирования системы государственного управления.

Баденского», Дух Журналов, 1818, ч. 31, декабрь, с. 629-660; «Государственное уложение Баварского королевства», Дух Журналов, 1818, ч. 31, ноябрь, с. 525-572; «Конституция Северо-Американских соединенных областей», Дух Журналов, 1820, ч. 38, кн. 2-3, с. $73-88$; кн. 3 , с. $97-116$; кн. 4 , с. $157-164$.

10. «Конституция Англии», Дух Журналов, 1817, ч. 17, кн. 5, с. 225-256.

11. М.М. Сперанский, «Введение уложению государственных законов (1809) (План всеобщего государственного преобразования», в М.М. Сперанский, План государственного преобразования: (Введение к уложению государственных законов 1809 г.), М.: Гос. публ. ист. б-ка России, 2004, с. 5-67; «Государственная уставная грамота Российской империи (1818 г.)» в Н.В. Минаева, Век Пушкина, М., 2007, приложение, с. 208-244; «Записка графа Воронцова о милостивом манифесте на коронацию императора Александра I, с материалами для сего манифеста», Русский архив, 1908, № 6, с. 4-18; Проект «Всемилостивейшей Жалованной Грамоты, Российскому народу жалуемой, 1801 г.», в Минаева, Век Пушкина, приложение, с. 149-160.

12. Мнение Мордвинова о правах Сената, Архив графов Мордвиновых, в 10 т., СПб., 1901 - 1903, т. 3, д. 748, с. 221-225; РГИА (Российский государственный исторический архив), ф. 1260, оп. 1, д. 376. 
Ответ на данный вопрос предполагает сопоставление мемуаров, дневников или частной переписки авторов проектов и содержания предложений по реализации в общероссийском масштабе принципа выборности. К сожалению, авторы наиболее известных конституционных проектов не зафиксировали свои впечатления от участия в выборных процедурах на уровне дворянских собраний. Однако это не означает их неосведомленность о том, что происходило на местном уровне. В большинстве случаев авторы проектов были членами Государственного совета или Сената. Данное обстоятельство, хотя и косвенно, позволяет предположить, что они были достаточно хорошо информированы о разнообразных нарушениях закона, выявленных в ходе сенаторских губернских ревизий, в том числе, и о содержании отдельных прошений об отмене результатов выборов или жалоб на нарушения процедуры голосования. Кроме этого они участвовали в обсуждении проектов по совершенствованию системы управления на губернском и уездном уровне ${ }^{13}$.

В самом начале царствования императора Александра I вопрос о возможности введения элементов выборности при формировании высших органов власти обсуждался в Государственном Совете. По инициативе императора, в апреле-мае 1802 г., членам Совета было предложено высказаться о целесообразности наделения Сената новыми функциями ${ }^{14}$. Большинство участников дискуссии считали несвоевременным расширение полномочий. Лишь некоторых из них подчеркивали, что для укрепления значимости Сената необходимо изменить порядок его формирования. Так, например, Н.С. Мордвинов представил свое «Мнение о правах Сената» ${ }^{15}$, в котором он подчеркивал, что существовавшая ранее практика назначения сенаторов предопределяла их зависимость от сиюминутной политической конъюнктуры. Все это нередко приводило к тому, что, при рассмотрении конкретных жалоб и прошений российских подданных одни и те же законодательные нормы трактовались в зависимости от субъективной позиции того или иного сенатора. Для восстановления «силы закона» и, одновременно, уменьшения вероятности установления деспотического правления или «всевластья министров», по мнению Н.С. Мордвинова, целесообразно было введение принципа выборности Сената. Конечно, речь шла не о предоставлении избирательного права неграмотным крестьянам, ремесленникам или купцам. Рассуждая о целесообразности превращения Сената в «тело политическое», автор утверждал, что политические права, концентрированным выражением которых является право избирать и быть избранным, должны принадлежать сословию, обладающему общественным доверием.

Предполагалось, что выборы должны проводиться по аналогии с установленными еще при Екатерине II правилами для избрания губернских

13. См., например: Архив Государственного Совета, т. 3, СПб., 1878, с. 55-66, 69-81, 167-176, 681-694.

14. Там же, т. 3, ч. 1, с. 15-50.

15. Мнение Мордвинова о правах Сената, т. 3, д. 748, с. 221-225. 
дворянских предводителей. К началу XIX века, по мысли автора проекта, Россия созрела для дальнейшего усовершенствования прежнего законодательства и «введения избрания... сенаторов от каждой губернии» (с. 224). Каждая губерния должна была быть представлена в Сенате двумя депутатами, избираемыми на три года. Главной их обязанностью объявлялось «... попечение о благе той губернии, от которой они избраны». При этом особо подчеркивалось, что избранные таким образом сенаторы не получали бы жалованья и должны были относиться к своим обязанностям как к общественному «служению» на благо Отечества. В такой трактовке формирование Сената посредством выборов воспринималось как органичное продолжение политики Екатерины II, предоставившей дворянству право «избирать между собою свободно своих судей и предводителей».

Несколько позднее, в 1810-1811 г., Н.С. Мордвинов предлагает новый проект создания в России выборного органа сословного представительства. Во всеподданнейшей записке «Для составления палат государственных ${ }^{16}$ oн обосновывал необходимость создания в России двухпалатного органа представительного правления общей численностью депутатов не более 400 человек, наделенного законотворческими функциями. Верхняя палата должна была формироваться по выбору губернских дворянских собраний по 1-2 чел. от каждой губернии. Для обеспечения независимости членов верхней палаты, они сохраняли свой статус пожизненно и получали фиксированное жалование из средств государственной казны. К выборам в нижнюю палату могли быть допущены все свободные российские граждане недворянского происхождения, обладавшие собственностью на сумму не менее 10 тысяч рублей серебром. К выборам допускались и бывшие крепостные крестьяне, получившие в соответствии с указом от 20 февраля 1803 г. статус «вольных хлебопашцев», при наличии у них в собственности не менее 1000 десятин земли.

Повлиял ли на обозначенные выше предложения Н.С. Мордвинова его личный опыт участия в выборных процедурах? На первый взгляд, содержание этих проектов является попыткой адаптации опыта английского парламентаризма, с которым Н.С. Мордвинов имел возможность ознакомиться в ходе длительных поездок по Европе. Но определенное влияние могло оказать и пребывание Н.С. Мордвинова на выборных должностях. О непосредственном участии в выборах мы узнаем из воспоминаний его дочери - Н.Н. Мордвиновой. В 1806 г. ее отец прибыл в Московское дворянское собрание, где проходило избрание предводителя земского ополчения (милиции) Московской губернии. На выбор собравшихся было предложено два кандидата - Н.С. Мордвинов и П.М. Дашков. И хотя, как подчеркивает Н.Н. Мордвинова, ее отец первоначально отказывался от участия в выборах, аргументируя это тем, что он «не московский», его известность и авторитет среди дворянства предопределили результат - единогласное избрание на 
должность предводителя ополчения ${ }^{17}$. Таким образом Н.С. Мордвинов на собственном опыте убедился, что главным критерием для избрания, кроме имущественного и возрастного ценза, должно было быть признание избирателями заслуг и способностей претендента на выборную должность. В данном контексте становится понятным его предложение о пожизненном статусе сенаторов Верхней палаты. Он предполагал, что члены дворянских собраний, понимая важность такого избрания, могут выдвинуть только наиболее уважаемых, «просвещенных» и ответственных представителей, которые, в силу отсутствия ограничения по времени пребывания в должности, получат возможность отстаивать в Сенате интересы своей губернии.

В целом авторы как собственно конституционных проектов, так и сугубо административных преобразований, проектируя возможные варианты применения в России выборных процедур, исходили из необходимости создания действенного механизма помощи императору при безусловном сохранении исторически сложившейся в России формы правления. С этих позиций выборы воспринимались не как средство формирования оппозиции верховной власти, а всего лишь как инструмент, поддержания стабильности позволяющий своевременно информировать и согласовывать позиции дворянства и императора. В данном контексте практически во всех подобных проектах неизменно воспроизводилась норма о необходимости установления имущественного и возрастного ценза. Такое ограничение позволило бы избежать возникновение острых конфликтов как между отдельными депутатами, так и между ними и чиновниками коронной администрации.

Несколько иная по отношению к самодержавной власти, но близкая по представлению о функциональном назначении выборов, схема прослеживается и в конституционных проектах, созданных участниками тайных обществ М.Н. Муравьевым и П.И. Пестелем. Не останавливаясь подробно на описании конкретных механизмов организации выборов и значении представительных структур в системе государственного управления и законотворчества, следует отметить, что принципиально важным вопросом, который задавали авторы проектов, был вопрос о соотношении нравственных и деловых качеств лиц, избираемых на различные должности. Сравнительный анализ текстов позволяет предположить, что по этому вопросу у авторов условно сложилось негласное конвенциональное соглашение, смысл которого сводился к ряду общих положений: 1) необходимо установить юридическую ответственность за препятствование, подкуп или насильственные действия, которые влияли бы на «свободный выбор народных представителей»; 2) в условиях имущественного неравенства российских граждан и географической протяженности империи необходимо создание многоуровневой системы выборных институтов. На каждом таком уровне была предусмотрена дробная дифференциация

17. Н.Н. Мордвинова, «Воспоминания об адмирале Николае Семеновиче Мордвинове и о семействе его. Записки его дочери», в Г.Н. Моисеева, сост., Записки русских женщин ХVIII - первой половины ХIХ века, М., 1990, с. 414-415. 
кандидатов на выборные должности по имущественному и возрастному цензу; 3) кандидаты на выборные должности, а также уже избранные представители, должны обладать определенными нравственными качествами. В противном случае, общее собрание депутатов имело право исключить за «недостойное поведение» или совершение преступления; 4) введение принципа личной неприкосновенности выборных представителей на все время исполнения ими своих обязанностей; 5) для предотвращения конфликта интересов необходимо запретить совмещение одним человеком выборных и иных официальных «гражданских должностей» ${ }^{18}$.

Конечно, перспектива реализации европейского принципа выборности на уровне центральных, общеимперских институтов не имела поддержки у дворянства в целом. Данное сословие было многократно дифференцировано по уровню материального благосостояния, образования и положения в чиновничьей иерархии. При таком положении перспектива установления, по аналогии со странами Западной Европы, конституции и создания выборных органов сословного представительства составляла горизонт социально-политических ожиданий лишь небольшой части представителей образованного дворянства. Более того, наряду со сторонниками расширения сферы применения принципа выборности на центральные органы власти, были и те, кто активно критиковал сложившуюся в ряде стран Европы практику избрания депутатов. Показательным примером может служить опубликованные в Духе журналов «замечания» на книгу Н.И. Тургенева, «Опыт теории налогов» ${ }^{19}$. Размышляя над работой Н.И. Тургенева, автор критически оценивал тезис о благотворном влиянии Английской конституции: «законы на бумаге удивительно хороши кажутся; но надобно посмотреть, какое действие производят, и каковы на деле?» ${ }^{20}$. Отвечая на свой вопрос, он последовательно доказывал, что существующий в Англии порядок избрания народных представителей и характер обсуждения законопроектов в парламенте, не позволяет говорить о реализации на практике провозглашенных принципов свободы и неприкосновенности собственности. Подкуп избирателей, неравномерность в распределении голосов, пассивность, неумение, а главное, нежелание отстаивать интересы народа - все это позволило автору статьи утверждать, что у английских депутатов «слово Конституция, благо общественное... в устах, но корысть и собственные выгоды в сердце...» ${ }^{21}$ В данном контексте подражание в России европейским парламентским структурам объявлялось нецелесообразным и даже опасным.

18. См.: «Конституция Н. Муравьева», Русская соичиально-политическая мысль. Первая половина ХІХ века. Хрестоматия, М.: МГУ, 2011, с. 161, 163, 166, 167, 168; П.И. Пестель, «Русская Правда, или Заповедная Государственная Грамота Великаго Народа Российскаго...», Там же, с. 275-277, 279.

19. Н.И. Тургенев, Опыт теории налогов, СПб.: тип. Н. Греча, 1818.

20. «Замечания на Опыт теории налогов», Дух журналов, 1820, кн. 5, с. 17.

21. Там же, с. 32. 
Одновременно с теоретическими размышлениями о возможных вариантах расширения сферы применения принципа выборности в общероссийском масштабе, не менее информативными для понимания процесса его адаптации, являются создаваемые по личной инициативе частных лиц практически ориентированные проекты. Как правило, такого рода проекты описывали не общее направление развития страны в неопределенной временной перспективе, а были нацелены на решение локальных задач, связанных с необходимостью упорядочения отношений между крестьянами и помещиками, и как следствие, повышения рентабельности дворянских хозяйств.

Одним из таких проектов была «Записка неустановленного лица о купеческом, мещанском и общеродовом праве». В разделе «О деревнях как исключительном имении дворян» автор предлагал целый комплекс правил, направленных на юридическую регламентацию взаимоотношений между помещиком, государством и крепостными крестьянами. Для осуществления взаимодействия с помещиком и выполнения различных обязательств в деревнях должны быть созданы выборные органы крестьянского самоуправления. К их компетенции были отнесены вопросы распределения земель между крестьянами, сбора доходов, платежей и податей, а также «...право воспомоществования из экономии деревенской, крестьянам преходящим в убыток» 22. Не менее важной функцией выборных людей было определение, кто из числа крестьян, и на какой срок должен быть определен «для домашних услуг помещику» ${ }^{23}$. По мысли автора проекта, такое право выборных от крестьян могло уменьшить вероятность возникновения конфликтных ситуаций между помещиком и общиной, которые неизбежно возникали, так как изъятие работника от полевых работ увеличивало нагрузку на всех остальных крестьян. Именно для уменьшения негативных экономических последствий автор предлагал ограничить право выборных людей назначать крестьян для службы в доме помещика. К таким работам могли быть определены «...крестьяне, пришедшие в упадок..., или молодые и еще неженатые» мужчины. При этом подчеркивалось, что женщины детородного возраста к службе в доме помещика могли быть назначаемы только при условии их добровольного согласия ${ }^{24}$.

Кроме осуществления функций хозяйственного управления и оказания помощи нуждающимся крестьянам, выборные структуры должны были уменьшить произвол помещика в отношении наказания крестьян. Для этого в проекте была предусмотрена норма, в соответствии с которой «все наказания за ленность и другие пороки, вредные для общественности, предоставляются выборным крестьянам» ${ }^{25}$. При этом подчеркивалось, что «наказания телесные имеет право делать только правительство», а обвинение крестьянина в совер-

22. РГИА, ф. 1260, оп. 1, д. 440, л. 22.

23. Там же, л. 23.

24. Там же, л. 24.

25. Там же, л. 21. 
шении уголовного преступления могло быть выдвинуто «по представлению выборных», засвидетельствованному местным священником ${ }^{26}$. Только после этого обвиняемый мог быть передан в соответствующие судебные инстанции. В данном контексте автор, по сути, предполагал создать процедуру досудебного общественного согласования, которая позволила бы помещику, формально заручившись поддержкой выборных, снять с себя часть ответственности за наказание крестьян. Таким образом, с позиции авторов подобного рода проектов, реализация принципа выборности на уровне отдельного помещичьего имения могла не только снизить вероятность возникновения острых конфликтных столкновений между помещичьей администрацией и крестьянами, но и изменить правовой статус крестьянина, который из объекта права с помощью выборных представителей становился субъектом правоотношений. Выборы рассматривались как инструмент согласования интересов внутри крестьянской общины. Формально, помещик как бы самоустраняется от внутренних споров и имел дело уже одобренным большинством голосов решением.

Однако такая перспектива не означала ослабления позиций помещика. Напротив, в целом ряде проектов, предусматривавших юридическое признание выборных крестьянских институтов, помещик оставался главной фигурой социального соотнесения. Особенно отчетливо попытка встроить внешне похожие на выборные институты при условии сохранения доминирующих позиций помещика, прослеживается в «Сельских уставах для крестьян», которые отдельные помещики пытались устанавливать в собственных имениях.

Одним из наиболее известных произведений такого рода был Опыт сельского устава для помещичьего имения, состоящего на оброке, изданный в 1819 г. В.Н. Каразиным ${ }^{27}$. По своей структуре и назначению данный устав является своеобразным аналогом «конституции», т.к. он определял структуру управления имением, функции «господина» ${ }^{28}$, права и обязанности крестьян. Система управления имением предполагала два взаимосвязанных уровня: 1) помещик и его представители; 2) органы крестьянского самоуправления. Непосредственным представителем «господина» был назначаемый сельский староста, который вместе с двумя «выборными» от крестьян входил в «Сельскую Думу», которая «...ведает всеми общественными делами без исключения» ${ }^{29}$. К компетенции «Сельской Думы» были отнесены следующие вопросы: 1) своевременная «раскладка» различных повинностей и «общественных сборов» в зависимости от «возраста и возможностей каждого поселянина»; 2) «исправление нравов поселян», то есть «наблюдение, чтоб они

26. Там же, л. 21, 26-27.

27. Опыт сельского устава для помещчичего имения, состоящегго на оброке. Временный устав сельйа Анашкина с деревнями, СПб.: тип. Н. Греча, 1819. Устав действовал в имениях В.Н. Каразина в Московской и Слободско-Украинской губернии.

28. В тексте устава помещик назывался «господином», что, на мой взгляд, могло вызывать определенные ассоциации с понятием «государь».

29. Опьт сельского устава для помещиичьего имения, с. 7. 
были благочестивые и честные люди»; 3) выдача из средств, оставшихся после уплаты всех податей, займов поселянам на срок от одного года до восьми лет $^{30}$. По письменному согласованию с помещиком, но не чаще 1-2 раз в год, «Сельская Дума» могла созывать «мирские сходки», на которых, под председательством приходского священника или старосты, все взрослые мужчины тайным голосованием решали наиболее важные вопросы ${ }^{31}$.

Предлагаемая автором «сельского устава» устава система управления предполагала, что помещик не только сохранял контроль над жителями селения, но и получал возможность своевременно узнавать о настроениях в крестьянской среде, а следовательно, и предупреждать развитие конфликтных ситуаций. Подтверждением этого может служить ряд положений, определявших взаимоотношения «поселян» и «господина»: 1) помещик добровольно возлагал на себя обязанность «охранять моральную чистоту» крестьян», а также «почитать, и заставлять почитать собственность каждого поселянина неприкосновенною» ${ }^{32}$; 2) помещик назначал своего представителя в сельскую думу («староста»), голос которого имел решающее значение, даже в том случае, если выборные от крестьян были с ним не согласны. При этом, по аналогии с установленным в Государственном Совете порядком, мнение несогласных в письменном виде преподносилось помещику; 3) крестьяне имели право прямого обращения к помещику с жалобой на решением «сельской Думы»; 4) «в затруднительных случаях Сельская Дума» должна обращаться за помощью к «господину» (помещику); 5) «сельская Дума» по итогам каждого месяца предоставляет помещику письменный отчет о своей работе; 6) сельский сход «без господского письменного приказа не может собираться» 33 .

Следует отметить, что для автора «Сельский устав» не существовал вне социального и политического пространства Российской империи. Напротив, он неоднократно подчеркивал его включенность в более широкие правовые и морально-этические отношения: в качестве не требующего дополнительного обоснования положения, утверждалось, что крестьяне должны проявлять уважение и послушание не только своему «господину», но и «государю». Именно поэтому первая статья «устава» была написана в форме отчетливо сформулированного наставления: «с поселян, прежде всего, взыскивается, чтоб они были христиане и верные подданные Царя своего не по имени только, но самим делом, т.е. исполняли бы все то, что законы Божий и Царский предписывают» ${ }^{34}$. В таком контексте отношения власти и подчинения не сводились к механическому исполнению приказаний, а предполагали взаимную преданность, ответственность и заботу.
30. Там же, с. $9,14$.
31. Там же, с. 7, 12, 13.
32. Там же, с. 15, 16.
33. Там же, с. 7, 8, 12.
34. Там же, с. 5. 
Таким образом, на проектном уровне осмысления принципа выборности можно констатировать двойственность ориентиров российских авторов. Следуя либеральной модели общественного устройства, в соответствии с которой достижение «общего блага» предполагает добровольное соединение усилий отдельных индивидов, авторы общероссийских проектов конституции воспроизводили принципы личной свободы, верховенства закона и неприкосновенности собственности. Одновременно с этим, важным смысловым акцентом, который отчетливо прослеживается как в проектах конституции общероссийского масштаба, так и локальных проектах «сельских уставов», было утверждение о приоритете «общего блага» над частными интересами. В данном контексте, на мой взгляд, можно констатировать не всегда осознанную попытку адаптировать к российской реальности начала XIX в. модель римского республиканизма ${ }^{35}$, предполагавшую бескорыстное служение граждан общему делу, но с сохранением монархии и патерналистских отношений между властью и гражданами. Для поддержания стабильного развития и недопущения повторения опыта европейских революций, принципиально необходимым представлялось сохранение органичной связи «конституции» с предшествующим российским законодательством и общинными традициями. Показательно, что синонимом понятия «конституция» был «коренной закон», а в названии проектов использовали словосочетания «Государственная уставная грамота», «Уложение государственных законов», «Государственный закон», «Государственный завет», или даже «Русская правда», которая, хотя и предполагала кардинальные преобразования, но на уровне ассоциативных связей апеллировала к одноименному памятнику древнерусского права ${ }^{36}$. Таким образом, подчеркивалось, что содержание российской «конституции» должно было стать результатом органического синтеза собственного исторического опыта и современных способов управления государством в развитых странах Европы.

\section{Практики электорального поведения: дворянские жалобы и прошения по вопросам организации выборов}

Обозначенные выше проекты возникали на фоне многолетней практики проведения выборов в уездных и губернских дворянских собраниях, органов городского самоуправления и земского суда. К началу ХІХ в. часть дворянства, которая в соответствии с действующим законодательством имела право

35. Данная модель во многом определила основы демократического республиканизма американской и французской революций. См., например: Gordon S. Wood, The Radicalism of the American Revolution, New York: Vintage Books, 1991.

36. См. подробнее: Д.В. Тимофеев, Европейские идеи в социально-политическом лексиконе образованного российского подданного первой четверти ХІХ века, Челябинск, 2011, c. 128-138, 299-332, 449-453. 
участвовать в выборах, уже имела опыт электорального поведения ${ }^{37}$ и отчетливо представляла себе, каким образом идеальная теоретическая модель была «встроена» в российскую реальность. Субъективно оценивая порядок подготовки, процедуру их проведения и итоги выборов, представители «благородного сословия» отмечали позитивные и негативные стороны избирательного процесса в целом. Критика существующего положения выражалась в составлении жалоб и прошений, адресованных как губернской, так и центральной администрации. Такую форму активности, наряду с участием выборах, следует, на мой взгляд, рассматривать как элемент электорального поведения.

Сравнительный анализ содержания жалоб и прошений по данному вопросу позволил определить несколько моделей электорального поведения до и после проведения выборов. Первая модель - обращение к власти с жалобами на избрание «недостойных кандидатов» или, напротив, отстранение дворянина от участия в выборах. В большинстве случаев подобные жалобы были связаны внутренними конфликтами, основанными на личной неприязни, стремлении отомстить за нанесенную ранее обиду или финансовые убытки. Так, например, губернский секретарь Симферопольского уезда Таврической губернии Василий Чернов в марте 1817 г. подал в министерство внутренних дел жалобу на предводителя губернского дворянства Таранова-Белозерова, в которой обвинил его в совершении «противозаконных поступков»: «лихоимстве»; «законопротивном подлоге», приведшем к уголовному преследованию двенадцатилетнего мальчика-сироты; использованию служебного положения для намеренного разорения отдельных дворян ${ }^{38}$. В ответ на все эти обвинения подполковник Таранов-Белозеров написал обширную (31 лист рукописного текста) объяснительную записку. Полностью отрицая все обвинения, он объяснял поведение доносителя желанием отомстить за «удаление» В. Черного от должности, принятие к рассмотрению прошения кредиторов о взыскании долгов и «... непричисление его к здешнему благородному сословию, поелику он происхождения низкого, а по чину есть только дворянин личной» ${ }^{39}$. В данном случае выборы служили лишь поводом составления жалобы, а главной причиной ее появления был имевший длительную предысторию личный конфликт.

Более распространенными были жалобы, возникавшие как реакция на включение «недостойных кандидатов» в избирательные списки. Одной из весомых причин, которая, по мнению авторов подобного рода документов, была достаточным основанием для лишения дворянина права быть избранным

37. В данном контексте использование термина «электоральное поведение» представляется вполне оправданным, так как дворянство было неоднородно и, как убедительно показывает в своих работах А.И. Куприянов, вполне адекватно позволяет описать внутренние противоречия между различными группами местного дворянства, которые одновременно выступали и в роли избирателей, и в качестве кандидатов на выборные должности. См. подробнее: Куприянов, «Дворянские выборы в последней четверти XVIII - первой трети XIX века...», с. 33-34.

38. РГИА, ф. 1306, оп. 1, д. 23, л. 2-5a.

39. Там же, л. 2-5a, 49. 
и «баллотировать» других кандидатов - нарушение морально-этических норм и «дурное поведение» ${ }^{40}$. Показательным примером может служить письменный протест, подписанный 20 дворянами Елецкого уезда Орловской губернии против допущения к выборам братьев Николая и Михаила Козелкиных, которых подозревали в «притеснении госпожи генеральши Замятиной» и «сожитии» одного из них в официально не оформленном браке ${ }^{41}$. Акцентирование внимания на несоответствии поведения дворянина определенным морально-этическим нормам обосновывалось авторами прошения стремлением допустить к выборным должностям лишь наиболее достойных представителей дворянского сословия.

В данном контексте отстранение от выборов воспринималось теми, кто по решению дворянских собраний лишался пассивного или активного избирательного права, как личное оскорбление, признание их «порочности» и серьезный удар по деловой репутации. С этих позиций для дворян лишенных права голоса важно было не столько собственно участие в выборах, сколько восстановление «доброго имени» и авторитета. Аналогичная риторика присутствовала практически во всех прошениях лиц отстраненных от участия в выборах. В одном из таких прошений майор Брянского уезда Орловской губернии Тютчев писал, что решение дворянского собрания об исключении его из избирательного списка было следствием «...зависти и неприятного расположения... трех брянских дворян», которые мстили ему за победу в торгах на право взимания питейных сборов ${ }^{42}$. Автор прошения искренне переживал свое «исключение» от выборов, оценивая данное решение как «оскорбляющий чувство чести... жестокий поступок дворян недоброходстующих» ${ }^{43}$. Отвергая выдвинутые против него обвинения в незаконном сожительстве с «внучатой крестной сестрой своей», он подчеркивал, что он уже более 15 лет состоит в браке с «...дннофамилкой по колену мужскому в шестой степени свойственнице», который был «утвержден... духовным правительством» ${ }^{44}$. Таким образом, по его словам, он «не нарушил никакого в общежитии порядка». Одновременно с опровержением подозрений в «недостойном поведении» Тютчев, обращаясь к императору, объяснил мотивы написания прошения и обосновал необходимость участия в выборах: главной причиной обращения к верховной власти с прошением об отмене решения дворянского собрания была «истинная ревность моя к общей пользе, честь и обязанность к деяниям, даровавшим мне звание дворянина» ${ }^{45}$.

40. РГИА, ф. 1284, оп. 3, 1803, кн. 11, д. 16, л. 48-52.

41. Там же, кн. 10, д. 33, л. 48-52.

42. Там же, кн. 11, д. 22, л. 153-154 об.

43. Там же, л. 154 об.

44. Там же, л. 155.

45. Там же, л. 153. 
Таким образом, сравнительный анализ жалоб на избрание «недостойных» кандидатов выявил двойственность мотивации обращения к властным структурам с прошением об отмене решений дворянских собраний. С одной стороны, сам факт включения в избирательные списки и участие в выборной процедуре субъективно воспринимался как подтверждение общественного признания заслуг и личных «добродетелей» дворянина. Если же этого не происходило, вне зависимости от наличия сугубо утилитарных, экономических интересов, возникал межличностный конфликт, разрешение которого представлялось возможным посредством обращения во властные структуры с жалобой или прошением. При этом в тексте жалобы, наряду с оправдательной риторикой и обвинениями конкретных обидчиков, обязательно присутствовало указание на стремление автора прошения способствовать достижению «общего блага».

Вторая, условно выделяемая модель электорального поведения - составление жалоб на «пристрастие в выборах», то есть сознательное нарушение предусмотренных законодательством правил их подготовки и проведения. Содержательно такого рода жалобы отражали субъективное отношение местного дворянства к выборам и позволяют выявить несколько стратегий поведения.

Первая стратегия - стремление любыми, в том числе и незаконными, методами получить большинство голосов и, как следствие, занять должность, открывавшую возможность лоббирования своих коммерческих интересов, содействуя в «желательном» решении дел по искам о разделе имущества, выплатам долговых обязательств и иным гражданским спорам в земских судах. Ярким примером реализации такой стратегии является поведение в сентябре 1803 г. дворянина Виленской губернии Мирского, который первоначально 344 голосами участников местного дворянского собрания был отстранен от участия в выборах за «дурное поведение». Однако он незамедлительно обратился с жалобой к военному губернатору и добился аннулирования результатов выборов. Вскоре было назначено повторное голосование, а Мирской был включен в список кандидатов на должность земского судьи. Для обеспечения желаемого результата, он не только прямо призывал голосовать за него, но и незаконно, под видом дворян имеющих право участвовать в избирательной процедуре, привлек к голосованию «беспоместных шляхтичей» и даже «переодетых в шляхетское платье крестьян» ${ }^{46}$. Через некоторое время после его избрания, 80 дворян подписали жалобу о допущенных в ходе голосования нарушениях и направили ее министру внутренних дел, но Мирской, все-таки, был утвержден на должности земского судьи.

Вторая стратегия электорального поведения может быть условно обозначена как договорная. Менее изощренным, по сравнению с махинациями Мирского, но более распространенным способом влияния на результаты голосования был предварительный сговор с потенциальными «избирателями». Смоленский военный губернатор С.С. Апраксин в записке министру

46. РГИА, ф. 1284, оп. 3, 1803, кн. 11, д. 16, л. 36. 
внутренних дел В.П. Кочубею сообщал, что фактически решение о том, кто из кандидатов должен получить необходимое количество голосов принималось за несколько дней до выборов. По его словам, «...дворянин, желающий быть избранным, или желающий избрать кого-либо к занятию важного поста в своем уезде, прежде отъезда в губернский город составляет партию» ${ }^{47}$ Создаваемая на непродолжительное время с целью повышения вероятности избрания определенного кандидата, такая «партия», по свидетельству автора, «...старается по возможности себя усилить числом, привлекая для умножения избирательных балов самобеднейших дворян» ${ }^{48}$. Потенциальным сторонникам определенного кандидата полностью оплачивался проезд до места голосования а, также все расходы, связанные с проживанием в губернском городе. Таким образом, по сути, осуществлялся подкуп «беднейших дворян», имевших право участвовать в выборах. Негативно оценивая сложившуюся практику, С. Апраксин писал, что желающие получить выборные должности действовали, руководствуясь «корыстолюбием», а приглашаемые ими мелкопоместные дворяне «...из глупости, праздности и недостатка, единственно желая доставить себе несколько недель угощения, употребляют во зло право дарованное благородному дворянству и вредят обществу» ${ }^{49}$.

Описанная в донесении С. Апраксина практика разделения участников дворянского собрания на так называемые «партии» была широко распространенным явлением при подготовке и проведении выборов. В некоторых случаях разногласия приводили к невозможности принятия решений в установленные законом сроки. Так, например, Малороссийский генерал-губернатор А.Б. Куракин по требованию министра внутренних дел вынужден был 27 октября 1805 г. написать объяснительную записку «О причинах продолжавших дворянское в Полтаве собрание сверх времени по обряду для того назначенного». Нарушение порядка проведения выборов, было обусловлено следующими обстоятельствами:

Настоящее дворянское собрание, быв разделено на две одна другой противоречащие партии, вместо того чтобы заниматься в назначенные мною по обряду дни выборами чиновников, объято было непрестанными трактациями, кои от разделения общества на партии ежечасно рождались, и до того, что съехавшись дворяне в собрание по назначении в восьмом часу утра, не прежде к действительному делу приступать могли, как в одиннадцатом и двенадцатом, а иногда и в первом часу пополудни. ${ }^{50}$

С точки зрения организации выборов, современники оценивали появление «партий» и многочисленные споры между участниками дворянских собраний

47. Там же, 1805 , кн. 22, д. 8, л. 167.

48. Там же, л. 167-167 об.

49. Там же, л. 167 об.

50. Там же, д. 14, л. 44 об. 
негативно, т.к. это могло приводить к нарушению регламента заседаний, затягиванию процедуры, а также составлению впоследствии многочисленных прошений и жалоб теми, кто оказывался недовольным результатами выборов. Однако ретроспективное осмысление сегодняшними историками позволяет увидеть во множестве интриг, подлогов, споров и внутренних конфликтов зарождение нового для России явления - политической конкуренции. При всей ограниченности и условности использования данного понятия к реалиям рубежа XVIII-XIX в., оно позволяет описать начальный процесс осознания возможности практического использования дарованных дворянству прав и преимуществ не только по отношению к другим сословиям, но главным образом внутри дворянского сообщества ${ }^{51}$. В данном контексте отсутствие осознания единства дворянского сословия, появление возможности «играть» на противоречиях между различными групповыми и индивидуальными интересами следует рассматривать как важный фактор, оказывавший влияние на начало формирования элементов гражданского общества. Особенностью этого процесса было то, что он не затрагивал сколько-нибудь значительную часть населения страны, а имел локальный характер, ограниченный рамками политически и экономически активной части дворянства.

О наличии политически инертных групп дворян, обладавших при этом правам участия в выборах, красноречиво свидетельствует все тоже донесение А.Б. Куракина. Наряду с описанием конфликтов между «партиями», он упоминает и о дворянах, которые намеренно, не принимали активного участия в дискуссиях, а с выражением «крайнего неудовольствия» предпочитали «...уезжать с собрания в свои квартиры, и возвращаться не прежде, как состоящая в них надобность в большем счете времени уже потеряна» ${ }^{52}$. В этой связи можно говорить о существовании еще одной стратегии электорального поведения - стратегии формального присутствия, а фактически уклонения от активного участия в избирательной процедуре. Подобная установка не означала отрицания необходимости выборов как дополнительного способа демонстрации принадлежности индивида к «благородному сословию», а являлась, по мнению автора донесения, следствием «привычки в деревнях своих располагать временем по воле их» ${ }^{53}$ и непонимания смысла многочасовых дискуссий. В крайней форме такой политический инфантилизм мог приводить к формальному избранию на должность кандидатов, которые не только не проживали в данной губернии, но даже не были лично знакомы с местным дворянским обществом ${ }^{54}$. Возможность подобного рода «избрания»

51. Политическая конкуренция в этот период времени не предполагала состязания программ или концептуальных моделей будущего развития, а проявлялась в борьбе отдельных кандидатов и их «сторонников» за получение возможности отстаивать свои личные интересы после избрания на должность.

52. РГИА, ф. 1284 , оп. 3, 1805, кн. 22, д. 14, л. 44 об.

53. Там же.

54. Куприянов, «Дворянские выборы в последней четверти XVIII - первой трети XIX века», с. 34-37. 
могла быть следствием желания заручиться поддержкой высокопоставленного чиновника.

Третья модель электорального поведения - составление прошений, с предложением либо снизить уровень формальных требований к кандидатам на выборные должности, либо упразднить в отдельных губерниях выборы как способ подбора работников на должности, предполагающие наличие у претендента необходимых профессиональных качеств. Такой прагматической позиции придерживались чиновники уездного и губернского уровня, которые в своей практической работе сталкивались с проблемой нехватки квалифицированных кадров. Так, например, Волынский вице-губернатор П.М. Грохольский просил министра внутренних дел разрешить ему, вопреки положениям указа от 2 марта 1805 г. ${ }^{55}$, «...определить к должности губернского секретаря заседателя земского суда Доморадского, который ранее уже дважды переизбирался на эту должность», но после повышения имущественного ценза не мог уже участвовать в выборах. Аргументируя свое предложение, П.М. Грохольский подчеркивал не только профессионализм Доморадского, но и сообщал позицию местного дворянства, которое «...почитает нужным оставить его при прежнем месте... потому, что опытностью своею может подавать пример другим от дворянства избранным...» ${ }^{56}$. Таким образом Волынский вице-губернатор главным условием, обеспечивающим эффективность системы управления признавал опыт практической работы, который невозможно было «измерить» посредством имущественного ценза, установленного для участия в выборах. При этом, не отвергая принцип выборности в целом, он просил сделать лишь исключение из общего правила, которое, по его мнению, было обусловлено сложившимися в Волынской губернии обстоятельствами.

Аналогичное обращение к министру внутренних дел с прошением об изменении порядка определения на выборные должности было составлено в мае 1805 г. гражданским губернатором Псковской губернии П.Я. Ламбздорфом. Ссылаясь на указ от 3 марта 1805 г., в соответствии с которым в целом ряде губерний выборы земских исправников были упразднены и введен новый порядок их назначения Сенатом по представлению губернатора и министра внутренних дел ${ }^{57}$, он просил распространить данное положение и на территорию Псковской губернии. Необходимость перехода от выборности к назначению земских исправников подтверждалась многолетней практикой, которая убедительно доказывала, что посредством избрания можно определить, кто из дворянства пользуется общественным доверием, но невозможно найти квалифицированных чиновников. По словам П.Я. Ламбздорфа, выборные

55. Указ «О порядке дворянских выборов в губерниях, от Польши присоединенных» был издан сенатом 3 марта 1805 г. и устанавливал повышенные, по сравнению с другими российскими губерниями, требования к имущественному цензу: дворянин, не обладавший недвижимым имением с доходностью менее чем 150 руб. в год не мог занимать выборные должности, см. ПСЗ, т. XXVIII, 1805, № 21.641, с. 883-884.

56. РГИА, ф. 1284, оп. 3, 1805, кн. 22, д. 15, л. 249-249об.

57. ПСЗ, т. XXVIII, 1805, № 21.648, с. 885. 
в нижних Земских судах «...исправники... не имеют и той способности и расторопности, каковыя в особенной сей части необходимо потребны...» ${ }^{58}$. Такое положение нередко приводило к затягиванию судебных разбирательств и вынесению неправомерных решений.

Наряду с указанием на неэффективность выборов, как инструмента отбора наиболее квалифицированных служащих, в докладных записках и прошениях указывалось еще одно негативное следствие избрания чиновников на должности в уездных и нижних земских судах. Получив свою должность благодаря поддержке участников так называемой «партии», или покровительству высокопоставленного чиновника, они оказывались зависимы и вынуждены были обслуживать интересы определенного круга лиц. Описывая такое положения выборных чиновников, С.С. Апраксин писал о «невозможности соблюсти должное беспристрастие и справедливость»:

...избранные ...к служению чиновники ... могут ли действовать по долгу их и по закону беспристрастно? Так как он сего места искал сам, или другие старались доставить оного для своей пользы, и известно ему, кто был сообщник его и противник, то уже натурально, что он первым необходимо наровить, а последним чрез то вредить должен. Сие есть необходимые последствия таковых выборов! ${ }^{59}$

Зависимость выборных чиновников, по мысли автора, не только негативно влияла на неукоснительное соблюдение законов, но и приводила к финансовым потерям как частных кредиторов, так и государства. Дело в том, что избранные на должность уездного судьи или земского исправника не решались требовать своевременной уплаты различных «долгов и недоимок» в государственный бюджет, а «оставляли все сие на произвол случая» ${ }^{60}$. Для исправления сложившейся ситуации Смоленский военный губернатор С.С. Апраксин, также как и Псковский губернатор П.Я. Ламбздорф, просил отменить выборность земских исправников и уездных судей, и назначать на эти должности чиновников по приказу Сената с согласия министра внутренних дел.

В общем виде, обоснование необходимости сокращения номенклатуры выборных должностей сводилось к двум основным аргументам. Во-первых, переход от принципа выборности к принципу назначения на должности, связанные с отправлением правосудия, с одной стороны, обеспечит независимость судебных инстанций от «пристрастных мнений», что неизбежно будет способствовать реализации высочайше объявленного Александром I курса на «восстановление силы закона», а во-вторых, позволит увеличить скорость принятия решений.

58. РГИА, ф. 1284, оп. 3, 1805, кн. 22, д. 10, л. 176 об.

59. Там же, д. 8 , л. 167 об-168.

60. Там же, л. 168 об. 
Сопоставление особенностей расстановки смысловых акцентов в процессе теоретического и практического освоения принципа выборности в России первой четверти XIX в. позволяет сделать несколько предварительных обобщений.

На уровне проектов, описывавших возможность использования принципа выборности в неопределенной временной перспективе, как в масштабах всей страны, так и в локальном пространстве помещичьих имений, российские авторы воспринимали выборы в качестве дополнительного инструмента согласования интересов дворянства и верховной власти, а иногда, даже помещика и подвластных ему крестьян. При этом предпринималась попытка либо встроить принцип избрания на определенные должности в уже существующие организационные структуры (Сенат, институты самоуправления в крестьянской общине и т.п.), либо, создавая новые органы, сохранить патерналистские по своему характеру отношения между выборными представителями и властью.

На рубеже XVIII-XIX вв. участие дворянина в выборах субъективно воспринималось как лично значимое право, подтверждающее его «благородство», общественное признание заслуг и способностей. Постепенно такая оценка и самооценка сформировала в сознании дворянина, чей возрастной и имущественный статус соответствовал законодательно установленным цензам, устойчивую мотивацию отстаивать свое право посредством написания прошений в вышестоящие инстанции, или напротив - жалоб на избрание «недостойных кандидатов».

Одновременно с морально-статусной составляющей, интерес к выборам был обусловлен и утилитарно-прагматическими соображениями. С начала XIX в. выборные должности рассматриваются наиболее предприимчивыми дворянами как своеобразный ресурс, с помощью которого можно было оказывать покровительство менее зажиточным дворянам в решении судебных тяжб и иных актуальных вопросов. В данном контексте, случаи сговора или подкупа выборщиков, составлявших так называемые «партии», а также жалобы на дворян уже избранных на должности с требованием аннулировать результаты голосования, отражают процесс становления в России начала XIX века элементов политической конкуренции и гражданского общества. Первоначальный импульс к началу этого процесса, так же как во Франции и Пруссии, исходил от верховной власти ${ }^{61}$, однако на уровне практических действий общественная активность отдельных дворян обосновывалось уже не только теоретическими рассуждениями о «благе общем», но и сугубо утилитарными интересами.

61. См.: Nancy Gina Bermeo, Philip G. Nord, Civil society before democracy: lessons from nineteenth-century Europe, Lanham, 2000; Д. Брэдли, «Гражданское общество и формы добровольных ассоциаций: опыт России в европейском контексте», в Б. Петров-Эннкер и Г.И. Ульянова, отв. ред., Гражданская идентичность и сфера гражданской деятельности в Российской империи. Вторая половина ХІХ - начало ХХ века, М.: РОССПЭН, 2007, с. 71-72. 
Сочетание морально-этического фактора и утилитарно-прагматических мотивов определило содержание критических замечаний относительно реализации принципа выборности в России. Констатируя дефицит квалифицированных чиновников и зависимость выборных работников от позиции тех, кто помогал им получить необходимое количество голосов, противники выборов акцентировали внимание властей на специфических особенностях различных регионов Российской империи, состояние кадрового потенциала в местных органах дворянского самоуправления и суда. При этом предлагался очень простой критерий оценки жизнеспособности выборных процедур применительно к каждой российской губернии: если выборы не приводят к главному результату - формированию профессионального, четко функционировавшего бюрократического аппарата, то целесообразно упразднить выборность и возвратиться к практике прямого назначения чиновников по приказу сверху.

В общем виде, проведенный анализ содержания проектов реализации принципа выборности в России и различных стратегий электорального поведения позволяет констатировать синкретизм и фрагментарность политических ориентаций российского дворянства. По аналогии с моделью «демократического республиканизма» декларировалась приверженность «общему благу» и готовность индивида исполнить долг «истинного гражданина» и, одновременно, стремление укрепить патерналистский характер взаимоотношений власти и подданных. На утилитарно-прагматическом уровне, при сохранении все той же риторики о приверженности «общему благу», выборы становились инструментом достижения частных интересов и, по сути, воспроизводили модель «сословного республиканизма», при которой институты сословного представительства существовали для защиты сугубо партикулярных интересов. Такая сложносоставная система ценностных ориентаций дополнялась идеализацией собственного исторического прошлого, обращением к опыту работы «Земских соборов», и констатацией невозможности подбора необходимых для функционирования государственного аппарата квалифицированных кадров посредством выборных процедур.

Уральский федеральный университет имени первого Президента России Б.Н.Ельцина/ Ural Federal University (UrFU)

Институт истории и археологии Уральского отделения РАН/

Institute of history and archaeology of the Ural branch of the Russian academy of sciences

dmitrtim@yandex.ru 